\title{
Comparison of sternal pain and narcotic requirement after cardiac surgery between new rigid closure and conventional wire closure: follow-up results of 50 randomizations.
}

\author{
Jeevan Kuman, BS \\ Thomas Jefferson University \\ James T. Diehl, MD \\ Division of Cardiothoracic Surgery, Jefferson Medical College, Thomas Jefferson University \\ Hitoshi Hirose, MD, PhD \\ Thomas Jefferson University
}

Follow this and additional works at: https://jdc.jefferson.edu/surgeryfp

Part of the Surgery Commons

\section{Let us know how access to this document benefits you}

\section{Recommended Citation}

Jeevan J, Unai S, Diehl JT, Hirose H. Comparison of sternal pain and narcotic requirement after cardiac surgery between new rigid closure and conventional wire closure: follow-up results of 50 randomizations. Presented at Chest 2013. Chicago IL. October 26-31, 2013.

This Article is brought to you for free and open access by the Jefferson Digital Commons. The Jefferson Digital Commons is a service of Thomas Jefferson University's Center for Teaching and Learning (CTL). The Commons is a showcase for Jefferson books and journals, peer-reviewed scholarly publications, unique historical collections from the University archives, and teaching tools. The Jefferson Digital Commons allows researchers and interested readers anywhere in the world to learn about and keep up to date with Jefferson scholarship. This article has been accepted for inclusion in Department of Surgery Faculty Papers by an authorized administrator of the Jefferson Digital Commons. For more information, please contact: JeffersonDigitalCommons@jefferson.edu. 


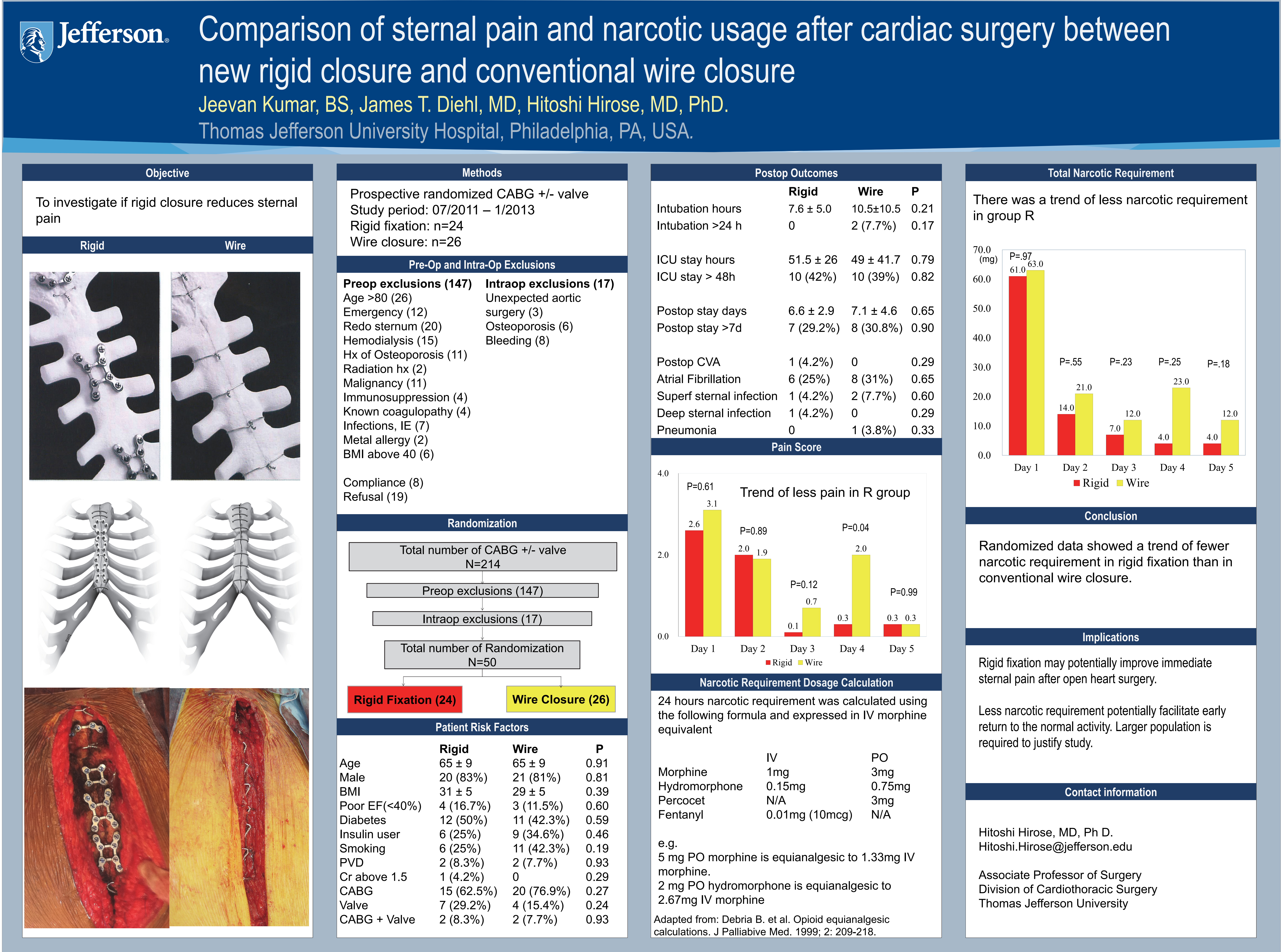

